Original Research Paper

\title{
Inovasi Teknologi Pembuatan Pakan Ayam Broiler Berbasis Bahan Baku Lokal
}

\author{
Bulkaini $^{1}$, Mastur ${ }^{1}$, Ashari ${ }^{1}$, I K Sumadi², dan I GNG Bidura ${ }^{2}$ \\ ${ }^{1}$ Fakultas Peternakan, Universitas Mataram, Mataram, Indonesia; \\ ${ }^{2}$ Fakultas Peternakan, Universitas Udayana, Denpasar, Indonesia;
}

https://doi.org/10.29303/jpmpi.v3i2.1071

Sitasi: Bulkaini., Mastur., Ashari., Sumadi, I. K \& Bidura, I. GNG. (2021). Inovasi Teknologi Pembuatan Pakan Ayam Broiler Berbasis Bahan Baku Lokal. Jurnal Pengabdian Magister Pendidikan IPA 4(4)

\author{
Article history \\ Received: 30 September 2021 \\ Revised: 10 Oktober 2021 \\ Accepted: 27 Oktober 2021 \\ *Corresponding Author: \\ Bulkaini, Fakultas \\ Peternakan, Universitas \\ Mataram, Mataram, \\ Indonesia; Email: \\ b_kaini@yahoo.com
}

\begin{abstract}
Inovasi teknologi pembuatan pakan adalah sebuah inovasi yang dapat mengolah limbah kulit nanas menjadi pakan ternak unggas dengan menerapkan teknologi fermentasi fakultatif anaerob. Tujuan dari penerapan inovasi teknologi ini adalah mengoptimalkan pemanfaatan beberapa bahan baku lokal (bekatul, jagung giling dan kulit nanas terfermentasi) menjadi pakan ternak unggas melalui Program Pemberdayaan Desa Mitra (PPDM) tahun 2021. Kegiatan ini telah dilakukan di Desa Sigar Penjalin yang bermitra dengan kelompok remaja masjid "Qomarul Huda Al-Hasanah" Dusun Cupek. Metode yang digunakan dalam melaksanakan program adalah metode Participatory Research Appraisal (PRA) yaitu bentuk metode yang melibatkan semua anggota mitra sasaran dalam melakukan program kerja. Dari program yang telah dilaksanakan, diperoleh hasil bahwa sekitar 95\% anggota kelompok remaja masjid siap melakukan usaha dibidang budidaya ayam broiler dengan menggunakan pakan yang bersumber dari bahan baku lokal. Hasil monitoring dan evaluasi menunjukkan bahwa pemanfaatan kulit nanas terfermentasi dalam dapat meningkatkan bobot potong ayam broiler dengan persentase karkas sebesar $68,12 \%$.
\end{abstract}

Keywords: Covid-19; Vaksinasi; Desinfektan; Kesehatan.

\section{Pendahuluan}

Ayam broiler merupakan salah satu jenis ayam yang dipelihara dengan tujuan untuk memproduksi daging sebagai salah satu sumber protein hewani. Ayam broiler merupakan ayam penghasil daging yang dipelihara sampai umur 6-7 minggu dan dapat mencapai berat 1,5-2 kg dengan konversi pakan 1,9-2(Ariana et al., 2018)

Faktor-faktor yang harus dipahami terlebih dahulu dalam pemeliharaan ayam broiler sebagai salah satu motivasi untuk melakukan usaha adalah harus mengetahui kelebihan dan kelemahan yang ada pada ayam broiler (Bidura et al., 2010). Selanjutnya dikatakan bahwa kelebihan ayam broiler adalah dagingnya empuk, ukuran badan besar, bentuk dada lebar, padat dan berisi, efisiensi terhadap pakan sangat tinggi, sebagian besar dari pakan diubah menjadi daging dan pertambahan bobot badan sangat cepat sedangkan kelemahannya adalah memerlukan pemeliharaan secara intensif dan cermat, relatif lebih peka terhadap suatu infeksi penyakit, sulit beradaptasi, dan sangat peka terhadap perubahan suhu lingkungan.

Tinggi rendahnya tingkat keuntungan yang diperoleh dalam pemeliharaan ayam broiler sangat bergantung pada harga pakan. Biaya pakan yang tinggi dapat diatasi dengan membuat ransum ayam menggunakan bahan baku lokal seperti jagung giling, bekatul dan limbah-limbah pertanian seperti kulit nanas. Dalam upaya untuk mengoptimalkan pemanfaatan bahan baku lokal sebagai pakan ternak unggas, dilakukan pengabdian kepada masyarakat 
dengan sasaran utama adalah anggota kelompok remaja masjid "Qomarul Huda Al-Hasanah" yang menjadi salah satu mitra dalam melaksanakan Program Perberdayaan Desa Mitra (PPDM) tahun ke tiga (2021).

Kegiatan pengabdian ini bertujuan untuk meningkatkan keterampilan anggota kelompok remaja masjid dalam membuat pakan ayam broiler dengan memanfaatkan bahan baku lokal seperti jagung giling, bekatul dan limbah kulit nanas terfermentasi. Hasil yang diharapkan dari pengabdian kepada masyarakat melalui PPDM adalah dapat meningkatkan keuntungan usaha peternakan ayam broiler skala kecil yang dilakukan oleh anggota kelompok remaja masjid "Qomarul Huda Al-Hasanah" Dusun Cupek Desa Sigar Penjalin Kecamaatan Tanjung Kabupaten Lombok Utara.

\section{Metode}

\section{Waktu dan Tempat}

Kegiatan pelatihan dan pendampingan usaha ayam broiler dilakukan selama 6 minggu (42 hari) di Dusun Cupek Desa Sigar Penjalin, Kecamatan Tanjung, Kabupaten Lombok Utara dari tanggal 1 Agustus sampai dengan tanggal 11 September 2021. Kegiatan pelatihan di lakukan langsung di lokasi kandang ayam yang dimiliki oleh kelompok Remaja Masjid“"Qomarul Huda AlHasanah".

\section{Alat dan Bahan}

Materi yang digunakan dalam pengabdian ini adalah DOC broiler sebanyak 100 ekor dengan bobot badan awal 36-40 g. Pakan ayam yang digunakan untuk DOC sampai umur 2 minggu diberikan pakan komersial CP 511 (pakan komplit butiran ayam pedaging). Ayam umur 3-6 minggu diberikan ransum yang disusun dengan bahanbahan: pakan komersial ayam broiler fase pertumbuhan (511B), jagung kuning giling, bekatul dan kulit nanas terfermentasi dengan kandungan protein kasar ransum $16 \%$ dan energi metabolisme (ME) sebesar $2.900 \mathrm{kkal} / \mathrm{kg}$, mineral $(\mathrm{Ca}: 0,60 \%$; Pav:0,35\%); dan asam amino (Met+Cys:0,60\% dan Lysine $0.90 \%$ ). Kandang yang digunakan untuk ayam umur 3-6 minggu berupa kandang sistem "battery colony" dengan ukuran $200 \mathrm{~cm}$ x $60 \mathrm{~cm}$ x $50 \mathrm{~cm}$ sebanyak 20 petak dan dilengkapi dengan tempat pakan dan air minum.

\section{Pelaksanaan kegiatan}

Kegiatan pengabdian diawali dengan proses fermentasi kulit nanas. Fermentasi kulit nanas dilakukan dengan metode fakultatif anaerob (Bidura et al., 2012). Diagram alir fermentasi kulit nanas disajikan pada Gambar 1.

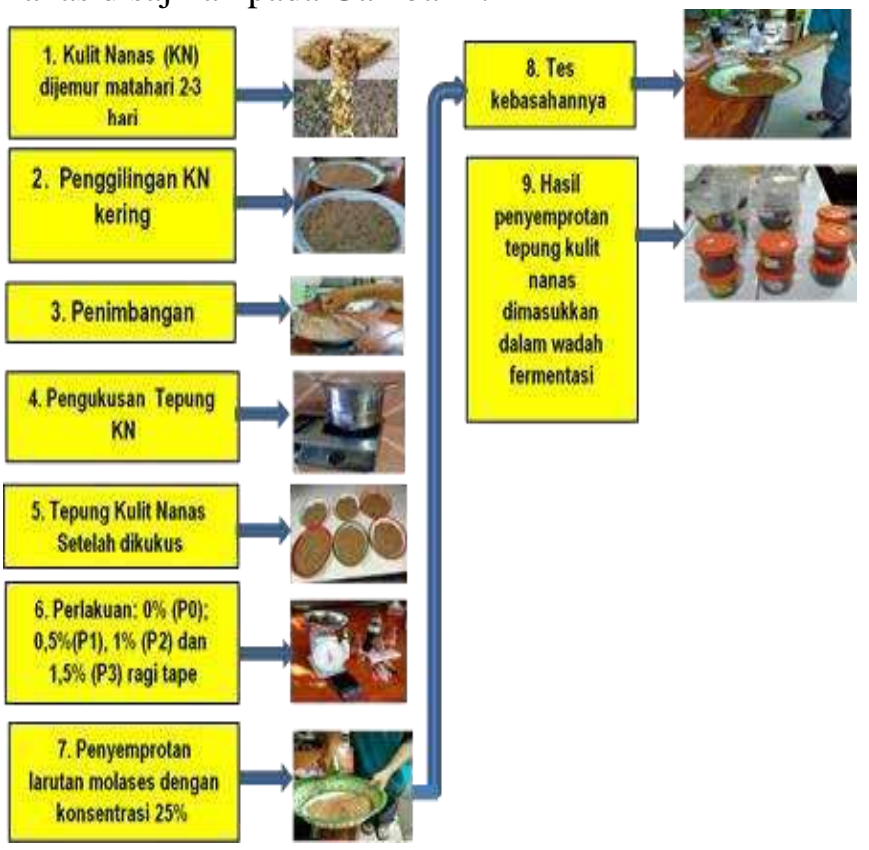

Gambar 1. Diagram alir fermentasi kulit nanas untuk skala uji Laboratorium.

\section{Hasil dan Pembahasan \\ Penyusunan ransum ayam broiler}

Materi pelatihan yang disampaikan kepada anggota kelompok remaja masjid "Qomarul Huda Al-Hasanah" yaitu pelatihan tentang pemanfaatan bahan baku lokal (jagung giling, bekatul dan serbuk kulit nanas terfermentasi) dalam penyusunan ransum ayam broiler. Guna mempertajam pemahaman tentang penyusunan ransum tersebut dilanjutkan dengan praktek penyusunan ransum seperti terlihat pada Gambar 2.

Substansi materi pelatihan yang disampaikan lebih difokuskan kepada perbandingan jumlah bahan-bahan yang diperlukan dalam penyusunan ransum sehingga mendapatkan kandungan protein kasar sebesar $16 \%$ dan energi metabolisme sebesar $2.900 \mathrm{kkal} / \mathrm{kg}$. Berdasarkan kandungan nutrisi masing masing bahan penyusun ransum (Pakan komersial 511B, jagung giling, bekatul dan kulit nanas fermentasi), dapat disusun formula ransum seperti terlihat pada Tabel 1 . 


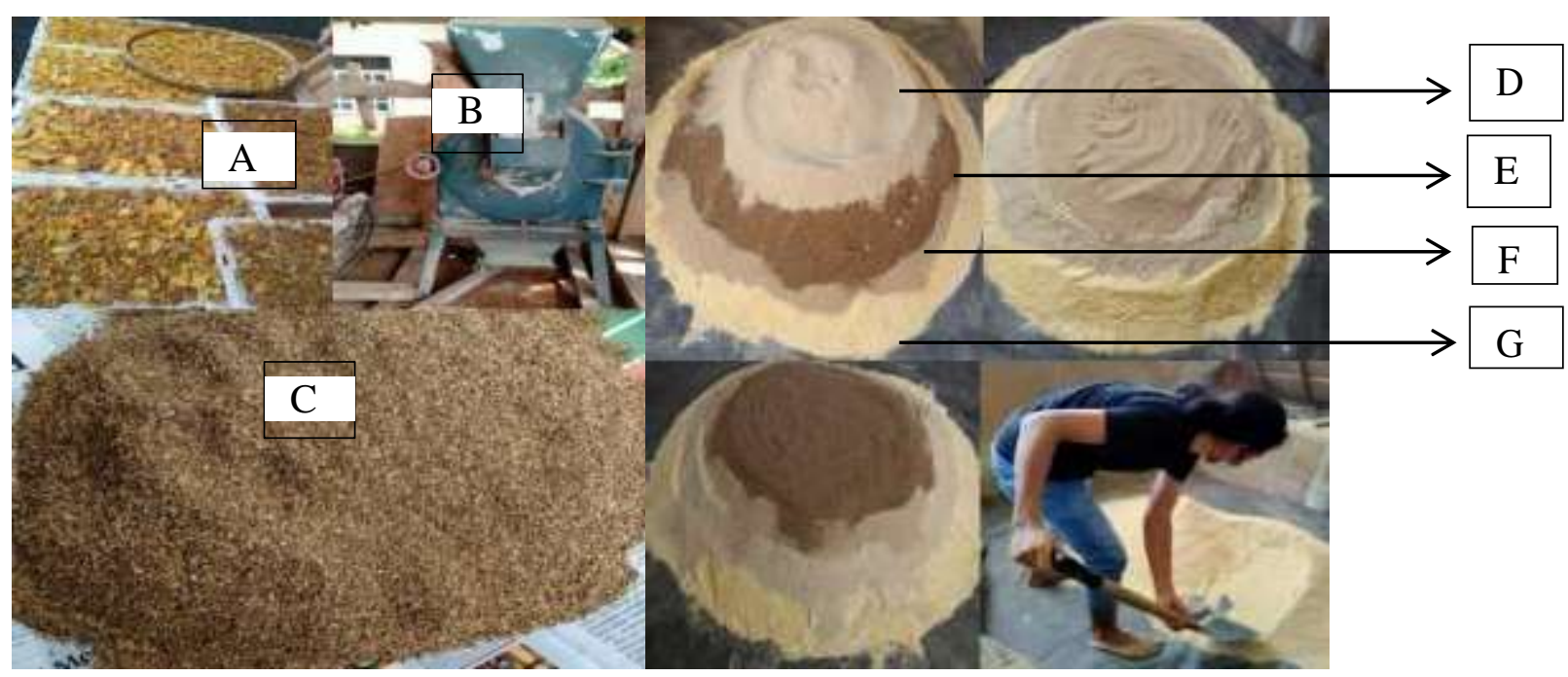

Tabel 1. Formula Ransum dan Kandungan Nutrisi Berdasarkan Perhitungan

\begin{tabular}{|c|c|c|c|}
\hline \multirow{2}{*}{ Komposisi Bahan (\%) } & \multicolumn{2}{|c|}{ Perlakuan } & \multirow[b]{2}{*}{$\mathrm{R} 2$} \\
\hline & R0 & $\mathrm{R} 1$ & \\
\hline Pakan komersial & 21 & 21 & 23 \\
\hline Jagung Giling & 55 & 48 & 48 \\
\hline Bekatul & 24 & 26 & 19 \\
\hline Tepung kulit nanas & 0 & 5 & 10 \\
\hline Minyak kelapa & & & (2) \\
\hline Jumlah & 100 & 100 & 100 \\
\hline $\mathrm{ME}(\mathrm{Kkal} / \mathrm{Kg})$ & 2929.70 & 2908.92 & 2910.06 \\
\hline $\mathrm{CP}(\%)$ & 16.38 & 16.01 & 16.16 \\
\hline SK $(\%)$ & 4.18 & 4.42 & 4.68 \\
\hline $\mathrm{EE}(\%)$ & 4,619 & 6.31 & 5.90 \\
\hline $\mathrm{Ca}(\%)$ & 0.66 & 0.65 & 0.71 \\
\hline $\operatorname{Pav}(\%)$ & 0.86 & 0.81 & 0.76 \\
\hline Metyonine+ Cys (\%) & 0.27 & 0.28 & 0.27 \\
\hline Lysine (\%) & 0.32 & 0.31 & 0.28 \\
\hline
\end{tabular}

Keterangan : Persentase minyak kelapa bersifat mencukupi kandungan ME

R0 : Pakan komersial $21 \%+55 \%$ jagung giling $+24 \%$ bekatul $+0 \%$ kulit nanas ter fermentasi

R1 : Pakan komersial $21 \%+48 \%$ jagung giling $+26 \%$ bekatul $+5 \%$ kulit nanas terfermentasi.

R2 : Pakan komersial 23\%+48\% jagung giling $+19 \%$ bekatul $+10 \%$ kulit nanas terfermentasi.

\section{Penerapan kulit nanas terfermentasi sebagai bahan penyusun ransum ayam broiler}

Penerapan kuit nanas terfermentasi sebagai pakan ayam broiler dicampur dengan jagung giling, bekatul dan pakan komersial. Jumlah ayam broiler yang digunakan dalam penerapan kulit nanas terfermentasi sebanyak 100 ekor Besar kecilnya respon ayam broiler yang diberi pakan campuran kulit nanas terfermentasi dapat dilihat dari bobot akhir, bobot potong, pertambahan bobot badan, feed conversion rasio (FCR) dan persentase karkas. Dari 100 ekor DOD ayam broiler, setelah umur 2 
minggu diambil 15 ekor untuk keperluan pengujian kualitas karkas ayam broiler dengan perlakuan sebagai berikut Perlakuan I $(\mathrm{P} 1)=$ Broiler diberikan pakan $100 \%$ pakan komersial; Perlakuan II $(\mathrm{PII})=$ Broiler diberikan pakan dengan susunan ransum $21 \%$ pakan komersial+48\% jagung giling $+26 \%$ bekatul dan $5 \%$ serbuk kulit nanas terfermentasi dan Perlakuan III (PIII)=Broiler diberikan pakan dengan susunan ransum $23 \%$

Tabel 2. Bobot Potong, Bobot Karkas dan Persentase Karkar Ayam Broiler Umur Potong 6 Minggu pada Tabel 2.

\begin{tabular}{lcrc}
\hline \multirow{2}{*}{ Variabel } & \multicolumn{3}{c}{ Perlakuan } \\
\cline { 2 - 4 } & $\mathrm{P} 1(0 \% \mathrm{KNF})$ & $\mathrm{P} 2(5 \% \mathrm{KNF})$ & $\mathrm{P} 3(10 \% \mathrm{KNF})$ \\
\hline Bobot potong (g) & $1.811^{\mathrm{a}}$ & $1.906^{\mathrm{a}}$ & $1.483^{\mathrm{b}}$ \\
Bobot karkas (g) & $1.367^{\mathrm{a}}$ & $1.439^{\mathrm{a}}$ & $1.259^{\mathrm{a}}$ \\
Persentase karkas (\%) & $60,65^{\mathrm{a}}$ & $59,81^{\mathrm{a}}$ & $68,12^{\mathrm{a}}$ \\
\hline
\end{tabular}

Keterangan : Superskrip yang berbeda pada baris yang sama menunjukkan perbedaan yang nyata $(\mathrm{P}<0,05)$

Hasil analisis one way anova menunjukkan level penggunaan kulit nanas fermentasi dalam ransum ayam broiler berpengaruh nyata $(\mathrm{P}<0,05)$ terhadap bobot potong ayam broiler, sedangkan terhadap bobot karkas dan persentase karkas tidak berpengaruh nyata $(\mathrm{P}>0,05)$. Hasil penelitian ini menunjukan bahwa bobot potong dan bobot karkas yang paling tinggi terjadi pada pemberian 5\% kulit nanas terfermentasi ragi tapi dalam ransum dengan persentase karkas yang paling rendah $(59,81 \%)$ dibandingkan dengan kontrol $(60,65 \%)$ dan perlakuan pemberian $10 \%$ kulit nanas terfermentasi ragi tape $(68,12 \%)$. Rendahnya persentase karkas pada perlakuan perberian 5\% kulit nanas fermentasi kemungkinan disebabkan karena bobot potong yang tinggi tidak sebanding bobot karkas yang dihasilkan, sehingga persentase karkasnya menjadi rendah. Tingginya bobot potong pada perlakuan 5\% kulit nanas terfermentasi ragi tape disebabkan karena perkembangan dari organ pencernaan ayam tersebut lebih dominan dibandingkan dengan perkembangan serabut otot sebagai komponen penyusun karkas. Hasil penelitian ini sejalan dengan pendapat Soeparno (2015) yang menyatakan bahwa jika pertumbuhan alat reproduksi lebih dominan dibandingkan dengan serabut otot dan tulang akan menyebabkan bobot karkas yang dihasilkannya rendah.

Hasil penelitian (Tabel 2) menunjukkan bahwa persentase karkas ayam broiler pada level pemberian $10 \%$ kulit nanas terfermentasi dalam ransum dapat menghasilkan persentase karkas $(68,12 \%)$ lebih tinggi dibandingkan dengan kontrol pakan komersial+48\% jagung giling dan 10\% serbuk kulit nanas terfermentasi. Variabel yang diukur dalam penerapan kulit nanas terfermentasi sebagai bahan penyusun ransum ayam broiler adalah bobot potong, bobot karkas dan persentase karkas dengan hasil pengamatan seperti disajikan

$(60,65 \%)$ dan level pemberian $5 \%$ yaitu $59,81 \%$.

Hasil penelitian ini memberikan gambaran bahwa pemberian kulit nanas terfermentasi ragi tape pada level $10 \%$ dapat menyebabkan pertambahan bobot karkas sejalan dengan pertambahan bobot badan sehingga dapat menghasilkan persentase karkas yang tinggi.

\section{Kesimpulan}

a. Kulit nanas terfermentasi ragi tape dapat dimanfaatkan sebagai salah satu bahan untuk menyusun ransum ayam broiler sampai level $10 \%$ dari total bahan penyusun ransum.

b. Penggunaan kulit nanas terfermentasi dalam ransum ayam broiler dapat mengatasi masalah pencermaran lingkungan yang diakibatkan oleh penanganan limbah kulit nanas yang tidak professional.

\section{Ucapan Terima Kasih}

Terima kasih disampaikan kepada Lembaga Penelitian dan Pengabdian Kepada Masyarakat Universitas Mataram yang telah memfasilitasi dalam pelaksanaan pengabdian kepada masyarakat melalui Program Pemberdayaan Desa Mita (PPDM) dengan sumber dana dari Badan Riset dan Inovasi Nasional. 


\section{Daftar Pustaka}

Ariana, I.N.T. G. A. M. Kristina Dewi, M. Wirapartha, I. W. Wijana, I. K. Anom Wiyana and N. W. Sitiari. 2018

Production and Income Over Feed and Chick Cost (IOFCC) of Broiler Chicken Which Feed The Fermented Dragon Fruit Skin Ration (Hylocereus Polyrhizus).Jurnal Ekonomi dan Bisnis Jagaditha.5(2): 92-96.

Bidura, I.G.N.G., D.P.M.A.Candrawati dan D.A.Warmadewi.2010.Pakan Unggas, Konvensional dan Inkonvensional. Udayana University Press, Unud. Denpasar.

Bidura, I.G.N.G., I.B. Sudana, I.G. Mahardika, I.P. Suyadnya, I.G.L.Oka, and I.A.I. Aryani. 2012. The Implementation of Saccharomyces spp.n-2 Isolate Tape (isolation from traditional yeast tape) for Improving Feed Quality and Performance of Male Bali Duckling. Agricultural ScienceResearch Journal. http://www.resjournals.com/ARJ/Index.htm . 2(9): 486-492.

Soeparno. 2015. Ilmu Nutrisi dan Gizi Daging. Gajah Mada University Press. Yogyakarta. Edisi Revisi Cetakan ke enam. 